\title{
"Låt lärarna vara lärare" - idéer om lärararbete i det offentliga samtalet om lärarassistenter
}

Per Lindquist

Linnéuniversitetet och Mälardalens högskola

\begin{abstract}
I artikeln uppmärksammas det offentliga samtalet i media om behovet av avlastning för lärare, $i$ vilket införandet av lärarassistenter förts fram som en potentiellt verkningsfull åtgärd. Med hjälp av en innehållsanalys av medietexter studeras det offentliga samtalet som en förhandling om gränser för lärares arbete som i förlängningen kan innebära en omdefiniering av arbetet. Den övergripande frågan i artikeln handlar om vilka olika idéer om lärararbetet som träder fram och som ges dominans i det offentliga samtalet. I studien diskuteras också hur det kan komma att påverka framtida förflyttningar av gränser kring framför allt den sociala dimensionen av lärararbetet. Resultatet visar att exponeringen av begreppet "lärarassistent" i media ökade kraftigt under början av 2016 samt att det offentliga samtalet har präglats av konsensus om idén om det "rena" lärararbetet där lärarna ska ägna sig åt undervisning och överlämna andra kringuppgifter åt antingen yrkesgrupper med lägre status i organisationen eller professionella yrkesgrupper med specialistkompetens. Studien visar också att det offentliga samtalet om införande av lärarassistenter i de svenska skolorna kan ses som ett steg på väg tillbaka mot en reduktion av lärararbetets sociala dimension, där lärarassistenter tar hand om det elevnära arbetet och där lärararbetet utanför klassrummet begränsas.
\end{abstract}

\section{INLEDNING}

Trycket på svenska lärare är högt. Måttliga PISA-resultat, en ökad redovisningsskyldighet för lärare samt en påtagligt ökande lärarbrist är bara några av de faktorer som bidrar till trycket (Bejerot, Forsberg, Kankkunen \& Hasselbladh, 2015; UKÄ, 2016). Under senare år har politiska initiativ tagits 
för att minska trycket mot lärarna. Bland annat har tvånget att upprätta skriftliga utvecklingsplaner inklusive skriftliga omdömen, varje termin för varje elev, upphört samt antal nationella prov reducerats. 2015 sjösattes dessutom det så kallade lågstadielyftet, där det gavs möjlighet för kommuner att söka statsbidrag för att utöka antalet lärare och annan personal i skolan. Flera andra förslag har legat på bordet. 2015 startades en nationell samling för läraryrket där regeringen bjöd in lärarfackliga organisationer och arbetsgivare till ett gemensamt arbete för att öka läraryrkets attraktionskraft och där ett av syftena var att frigöra tid "så att lärare kan vara lärare" (DN, 2016a). 2016 presenterades förslag på hur effekter av lärarbristen ska kunna reduceras genom att bland annat behålla lärare som är på väg att pensionera sig, återrekrytera pensionerade lärare samt anställa lärarstudenter i skolan (SOU 2016:35). I samma betänkande görs bedömningen att "frågan om lärarassistenters funktion i skolan bör utredas vidare" och att det också bör "övervägas om en nationell utbildning som leder till lärarassistent bör anordnas" (a.a., s. 14).

Förslag om att inrätta lärarassistenttjänster på skolor i syfte att avlasta lärare har under senare år framförts av olika aktörer i olika media. Såväl de lärarfackliga organisationerna som företrädare för olika politiska partier har återkommande propagerat för att införandet av en sådan ny yrkeskategori skulle kunna dämpa problemen med lärarbrist och lärarstress (se t.ex. DN, 2016a; SvD, 2016 och Skolvärlden, 2017). Argumenten har burit frukt. Hösten 2019 erbjöd regeringen nära 500 miljoner i statsbidrag till skolor som vill anställa lärarassistenter. Från och med 2020 fortsätter satsningen, nu med 1 miljard kronor årligen. I föreliggande artikel betraktas förekomsten av argumenten som ett offentligt "samtal" som utgör en del av en svängning i det offentliga samtalet om skolan och lärararbetet - ett nytt policyläge - som i förlängningen kan innebära en omdefiniering av lärares arbete. En fråga $i$ artikeln berör således vilka olika idéer om lärararbetet som träder fram och som ges dominans $i$ det offentliga samtalet om läraravlastning.

Introduktionen av en ny läraravlastande yrkesgrupp bör rimligen innebära att företrädare för den nya yrkesgruppen träder in i lärararbetets verksamhetsdomän (Grape, Blom \& Johansson, 2010), att arbetsuppgifterna kommer att delas upp och att domänen kommer att avgränsas på ett nytt sätt. I det offentliga samtalet bör det gå att spåra vilka avgränsningar som upprättas och vilka domänanspråk som görs för/tilldelas den nya yrkesgruppen respektive lärare. En sådan analys går att koppla till professionsteoretiska resonemang. Argumentation i media kan betraktas som en professionaliseringsprocess där differentieringen av lärararbetet beskrivs som en kamp om territorier, som "an object of struggle among contending groups or classes" (Friedson, 2001, s. 43) där de olika aktörerna genom "demarcationary strategies" (Boyce, Borthwick, Moran \& Nancarrow, 2011, s. 191) markerar sina revir. Hur lärarassistenter samt deras arbetsuppgifter, roller och funktioner definieras i 
det offentliga samtalet kan med andra ord ses som uttryck för förhandlingar om läraryrkets jurisdiktion, det vill säga om exklusiv kontroll över en verksamhetsdomän (Abbott, 1988). Utifrån ovanstående resonemang kan det vara intressant att komplettera frågan om domänanspråk med andra mer specifika och teoretiskt inspirerade frågor som: Hur markeras professionella gränser och revir? Av vem? Vilka gränstvister kan identifieras? Vilka hierarkier skapas?

Landahl (2006) visar i sin historiska analys av lärares arbete hur gränserna för lärares ansvarsområde, genom omförhandlingar, kontinuerligt förflyttas. Resultat från hans studie visar hur den sociala dimensionen i lärares arbete tilltagit och ändrat karaktär under slutet av 1900-talet och början av 2000talet. Läraren har, under denna period, givits ett allt större ansvar att ta hand om det elevsociala arbetet och därför tvingats "sträcka ut sig själv" (s. 99) utanför klassrummet. I föreliggande artikel betraktas det offentliga samtalet $\mathrm{i}$ media om införandet av avlastande tjänster som ännu en omförhandling om professionella gränser, som kan medverka till att gränserna för lärares ansvarsområde ånyo förflyttas. I en diskussion av studiens resultat behandlas därför frågan om hur omförhandlingen kan påverka framtida förflyttningar av gränser kring lärararbetet. Även om studien uppmärksammar formuleringsarenan finns alltså ambitionen att diskutera konsekvenser på realiseringsarenan (Lindensjö \& Lundgren, 2000).

En utgångspunkt för artikeln är att det offentliga samtalet om avlastning har konsekvenser för det framtida lärararbetet. Självklart finns andra betydande påverkansfaktorer men media har en framträdande roll i formandet av människors åsikter och bilder av verkligheten och, i förlängningen, deras handlingar (Strömbäck, 2009; Strömbäck \& Esser, 2014; jfr Englund, 1999). Vad som omtalas eller inte omtalas anger betingelser och villkor för de fenomen som benämns och för den verksamhet som omger dem. I föreliggande fall får det konkreta konsekvenser för verksamheten i skolan hur media ger plats åt olika aktörer att konstruera vissa fenomen som problematiska och hur något gestaltas som en potentiell lösning på dessa problem (Elstad, 2009; Stark, 2019). Liksom Wiklund (2006) vill jag hävda att medietexter utgör ett betydande bidrag till att formera utbildning, skola och lärararbete som specifika objekt. Texterna ger således en potential för förändring av lärares arbete. De erbjuder uppgifter att utföra och positioner att inta för lärare men även för andra parter som till exempel lärarassistenter.

\section{"SMUTSIGA" INSLAG I LÄRARARBETET}

Landahl (2006) beskriver i sin historiska studie av lärararbetet att det alltid haft diffusa gränser och inkluderat inslag som betraktats som främmande. Redan 1919 påtalar lärare att "Tiden är full av nya uppgifter, som man vill lägga på skolan” (a.a., s. 4). Landahl föreslår att vi kan förstå talet om fel- 
placerade inslag i termer av renhet och "smuts". Han refererar till antropologen Mary Douglas (1966/1992) som menar att smuts kan ses som felplacerad materia, som genom sin felplacering bryter mot en viss föreställning om ordning. Arbetsuppgifter kan på så sätt uppfattas som "smutsiga" om de går emot vissa föreställningar om vad yrkets innehåll bör vara. Läraryrkets "smutsiga" dimensioner kan förstås på skilda sätt. Antingen som att läraren är ovärdig arbetsuppgiften eller som att uppgiften är ovärdig läraren.

Resultat från Landahls studie visar att diskussionen om "smutsiga" inslag $i$ arbetet varit en ständig följeslagare genom läraryrkets historia och att förhandlingar om "rent" och "smutsigt" i läraryrket återkommande har relaterats till frågor om arbetsdelning, till ett eventuellt införande av andra yrkesgrupper i skolan. Ett sådant exempel är introduktionen av kuratorer i skolan. De första kuratorerna tillsattes redan under 1940-talet med främst yrkesrådgivning som arbetsuppgift. Under slutet av 1960-talet övertogs emellertid sådana arbetsuppgifter av så kallade studie- och yrkesorienteringskonsulenter (SYO). Kuratorerna kom istället att bli skolans sociala "expert" dit elever och deras föräldrar kunde vända sig för att få råd. Kuratorn fick också rollen som samordnare och länk till de sociala myndigheterna (Isaksson \& Larsson, 2012; Backlund, 2007). Kuratorernas nya funktion kom till stånd bland annat på grund av barnagans bortskaffande 1958 och den påföljande debatten i lärarkåren om vem som skulle ta hand om barns och ungas fostran i skolan (Backlund, 2007). Sådana arbetsuppgifter betraktades alltså som "smutsiga" och ansågs kunna hanteras av andra, bättre lämpade, yrkesgrupper. Fler kuratorer i skolan var därför villkor som vid den tiden framfördes av lärarkollegierna.

Omdefinieringen av kuratorernas arbete kan ses som ett tecken på hur den sociala dimensionen i lärararbetet kom att tränga sig på och hur detta försökte hanteras genom bland annat arbetsdelning. Landahl visar också hur den sociala dimensionen i lärararbetet vuxit sig starkare bland annat för att skolan, liksom samhället, under senare decennier genomgått en intimiseringsprocess i vilken närhet mellan människor ses som ett ideal. En sådan process har bidragit till att läraren givits ansvar att ta hand om elevers lidande. Den hjälpsökande eleven har därmed blivit ett självklart objekt för lärares arbete. Tidigare förväntades läraren sluta klassrummet för eleverna, genom att upprätta en skarp gräns mellan lektion och övrigt. Från och med slutet av 1900-talet förväntades emellertid läraren "sträcka ut sig själv" (s. 99) även till den tid då och de platser där eleven lämnat klassrummets panoptiska struktur. Även Backlunds (2007) studie om elevvård i grundskolan visar på hur den sociala dimensionen av lärararbetet växt sig starkare under början av 2000talet. Hon beskriver hur lärarna givits ett allt större ansvar för det elevsociala genom att elevvårdspersonalens arbete kommit att inriktas mot att ge indirekt stöd via konsultation till lärarna. Företrädare för elevvården har lyckats 
definiera sig som "konsulter" och inte som "lärarservice". På så vis har de gjort sig mindre tillgängliga för skolans elever. Dessutom hindras lärarna från att "lämna över problem" utan tvingas istället "bära dem själva". Eller med andra ord, elevvårdspersonalen har lyckats avgränsa sin verksamhetsdomän genom att "smutsigt" arbete, i form av direkt elev- och föräldrasocialt arbete, lastats över till lärarna.

\section{LÄRARES ARBETE I MEDIA}

Inom svensk utbildningsvetenskaplig forskning har relationen mellan medier och lärares arbete studerats i påfallande låg grad. Exempel finns emellertid på närliggande studier om mediernas funktion i debatten om skolan (FolkeFichtelius, 2003), om den krisinriktade mediedebatten kring svensk skola (Melander, 2004), om medias konstruktion av offentlig utbildning (Reimers, 2014), om medias roll i utbildningspolicy (Wiklund, 2018), om hur lokalmedia konstruerar problemrepresentationer av "den goda skolan (Stark, 2019) samt om medias framställning av svensk lärarutbildning (Edling \& Liljestrand, 2019). Ett fåtal studier har ett mer direkt fokus på lärare och lärares arbete. Ett exempel är dock Wiklund (2006) som undersöker hur Dagens Nyheter konstruerar "den gode läraren" enligt en konservativ och neo-liberal diskurs. Av intresse för föreliggande studie är också de professionsteoretiska studier av lärarfackens uttryck i media som bedrivits inom svensk utbildningsvetenskaplig forskning. Lilja (2014) har studerat de svenska lärarfackens reaktioner på politiska reformer under 2008. Genom att analysera debattartiklar, remissvar och visionsdokument visar Lilja bland annat att lärarfackens röst framstått som relativt svag på grund av uppdelningen i två fackförbund med olika idéer om vad som utgör den professionella kunskapsbasen. Här beskrivs även hur lärarförbunden, i sina debattartiklar, försöker bygga legitimitet för sin lärarprofessionalitet $i$ relation till allmänheten, genom att till exempel likna sitt skrå vid en mer etablerad profession som läkarprofessionen. Även Ringarps (2011) studie av motiven bakom kommunaliseringen av lärarkåren visar hur förhandlingar om lärarprofessionens jurisdiktion tar sig uttryck $i$ bland annat förbundens tidningar samt i pressklipp. Persson (2008) behandlar, i sin studie av läraryrkets villkor och organisering de senaste 200 åren, hur lärarnas fackliga förbund under senare decennier alltmer börjat visa uttryck för en professionell logik. Dessutom visar Sjöbergs (2010) studie hur lärarförbunden använder policyretorik om "den professionelle läraren" för att utveckla och skydda sin professionella status, bland annat i frågan om legitimering av lärarkåren.

Inte heller inom den internationella forskningen om relationer mellan media och lärararbetet är utbudet av forskning stort. Här ges dock ett större utrymme åt studier om medias roll $\mathrm{i}$ relation till utbildningspolicy (se t.ex. 
Anderson, 2007; Hattam m.fl., 2009; Piazza, 2014). Några studier finns emellertid som mer direkt fokuserar förhållandet mellan media och lärares arbete. Representationer av lärares yrkesidentitet har studerats i såväl amerikansk media (Cohen, 2010) som i en jämförande studie i fem länder (Alhamdan m.fl., 2014). Medias representation av lärare och hur den, under 2000-talets början, ges en allt mer positiv beskrivning har utforskats (Hansen, 2009). Även medias konstruktion av diskurser om lärare och lärarkvalitet, och hur dessa samspelar med policy har belysts (Thomas, 2011). Dessutom har Elstad (2009), i en norsk studie, behandlat medierepresentationer av kunskapsmätningar. Likt föreliggande studie intresserar sig Elstad även för konsekvenser på skolnivå av medieexponering och finner att en sådan på olika sätt påverkar lärares arbete.

\section{METOD}

Undersökningen i föreliggande studie baseras till övervägande del på träffar i Mediearkivet, en databas där de flesta svenska dagstidningar samt tidskrifter, nätsajter och telegrambyråer ingår. Mediearkivet är Nordens största digitala nyhetsarkiv och ägs av Retriever Sverige $\mathrm{AB}$. Användningen av databasen Mediearkivet ger en relativt heltäckande åtkomst till tryckta och digitala redaktionella medier under den undersökta perioden, däremot saknas annan media som till exempel radio, TV och social media. Urvalet kan därför medföra visa begränsningar, framför allt eftersom tryckt press läses och riktar sig emot den äldre delen av befolkningen. $\AA$ andra sidan innehåller Mediearkivet även digital press vilken idag konsumeras $\mathrm{i}$ allt större utsträckning av unga och yngre medelålders (Myndigheten för press, radio och TV, 2019). Även om Mediearkivet inte omfattar flera av de nya digitala plattformar där offentliga samtal förs idag går det att hålla för troligt att träffar på databasen till stor del speglar det offentliga samtalet om lärarassistenter. Det går dock inte att utesluta att andra plattformar, som till exempel social media, kan ge utrymme för andra typer av argument än de som blir synliga i föreliggande studie.

Urvalet av undersökta texter baserar sig på en introducerande sökning på förekomsten av begreppet lärarassistent*, $i$ såväl tryckt som digital press, under den senaste tioårsperioden (juli 2008 - juni 2018). En första översiktlig granskning visade att begreppet fram till 2014 mycket sällan brukades som ett argument för läraravlastning. Av den anledningen begränsades tidsperioden för det första urvalet av texter (Urval A) till fyra år, juli 2014 till och med juni 2018. Däremot behölls sökordet lärarassistent*. En genomgång av artiklar som erhållits med hjälp av sökningar på andra tänkbara relevanta begrepp som "socialpedagog", "läraradministratör", "skolresurs", "elevkoordinator" och "heltidsmentor" visar att antalet träffar minskar betydligt samt att begreppen mycket sällan används i samband med en argumentation för avlastning av 
lärare. Om så är fallet görs detta oftast i relation till begreppet lärarassistent. Det verkar med andra ord som att det offentliga samtalet om nya läraravlastande yrkeskategorier till övervägande del benämner dessa som lärarassistenter. Möjligen kan det vara så att en senare faktisk implementering av sådana tjänster i skolan ger upphov till andra benämningar.

Eftersom mängden träffar i urval A var så pass omfattande (2655) krävdes ett nytt urval (Urval B) där mängden texter kunde begränsas men ändå vara representativt (98). Avgränsningen gjordes genom att utföra en sökning på förekomsten av begreppet lärarassistent* i källkategorin storstadspress. Här gjordes också en bortrensning av artiklar där begreppet inte utgör en central aspekt av texten utan istället används i perifer bemärkelse. Ytterligare ett urval gjordes (Urval C) genom att sålla bort texter som inte direkt kan uppfattas ha en argumenterande karaktär. Kvar i urval C är alltså endast artiklar som bygger på olika aktörers argument (85).

Till slut valdes också texter som kan återspegla konsekvenser av det offentliga samtalet. Urvalet (Urval D) består av två texter. Den ena är regeringens uppdrag till särskild utredare att bland annat se över lärares administrativa arbetsbörda (Dir 2016:76). Den andra är samma utrednings slutbetänkande (SOU 2018:17).

Det empiriska materialet har analyserats med hjälp av innehållsanalys (Bergström \& Boréus, 2000; Bryman, 2008). För det första har en kvantitativ analys genomförts av det manifesta och explicita innehållet i det offentliga samtalet om lärarassistenter. Ansatsen är här summerande (Hsieh \& Shannon, 2005) för att ge en överblick över, och för att kunna urskilja mönster $i$ samtalet. Här har avsikten varit att erhålla en bild av samtalets utbredning, vilka som deltagit i samtalet och i vilken omfattning olika aktörer deltagit. En liknande kvantitativ analys har även genomförts av argumenten i samtalet. Syftet har varit att visa fram vilka argument som framförs, vem som framför dem, vilka argument som ges större/mindre uppmärksamhet samt hur argumenten och uppmärksamheten förändras över tid. Som en del av analysen har även ingått att redovisa hur aktörer väljer att beteckna den nya yrkesgruppen samt vilka arbetsuppgifter och vilken behörighet/kompetens de ska ha.

För det andra har en kvalitativ analys genomförts av det latenta och implicita innehållet i samtalet. Ansatsen är här av mer styrd karaktär (Hsieh \& Shannon, 2005). Som tolkningsram för analysen har teoretiska begrepp som kan kopplas till professionaliseringsprocesser (exempelvis markering av professionella gränser, specialisering av arbete, distribution av arbetsuppgifter) använts. Syftet har här varit att utveckla den kvantitativa analysen genom att förstå argumenten som uttryck för läraryrkets differentiering. Styrande för analysen har varit att söka efter tecken på hur lärararbetets verksamhetsdomän definieras samt vilka domänanspråk som görs med hjälp av gränsmarkeringar. På det sättet har inledande professionsteoretiska 
resonemang gett riktning och systematik. Samtidigt har tolkning av data haft ett reflexivt drag (Alvesson \& Sköldberg, 1994) i och med att teoretiska idéer har tillåtits att härledas utifrån insamlade data.

\section{RESULTAT}

Resultatkapitlet delas in i tre delar. I de två första delarna presenteras den kvantitativa analysen av samtalet och de ingående argumenten. I den sista delen redogörs för den kvalitativa analysen av argumenten.

\section{Lärarassistent* - förekomst av begreppet}

Figuren nedan (Figur 1) visar hur begreppet "lärarassistent" förekommer relativt sparsamt i svensk media fram till 2016, då det sker en betydande exponering av begreppet. Användningen av begreppet ökar markant under första halvåret 2016 för att sedan minska något. Under andra halvan av 2017 och i början av 2018 ökar exponeringen igen.

Figur 1. Mediaexponering av lärarassistent* över tid i Mediearkivet

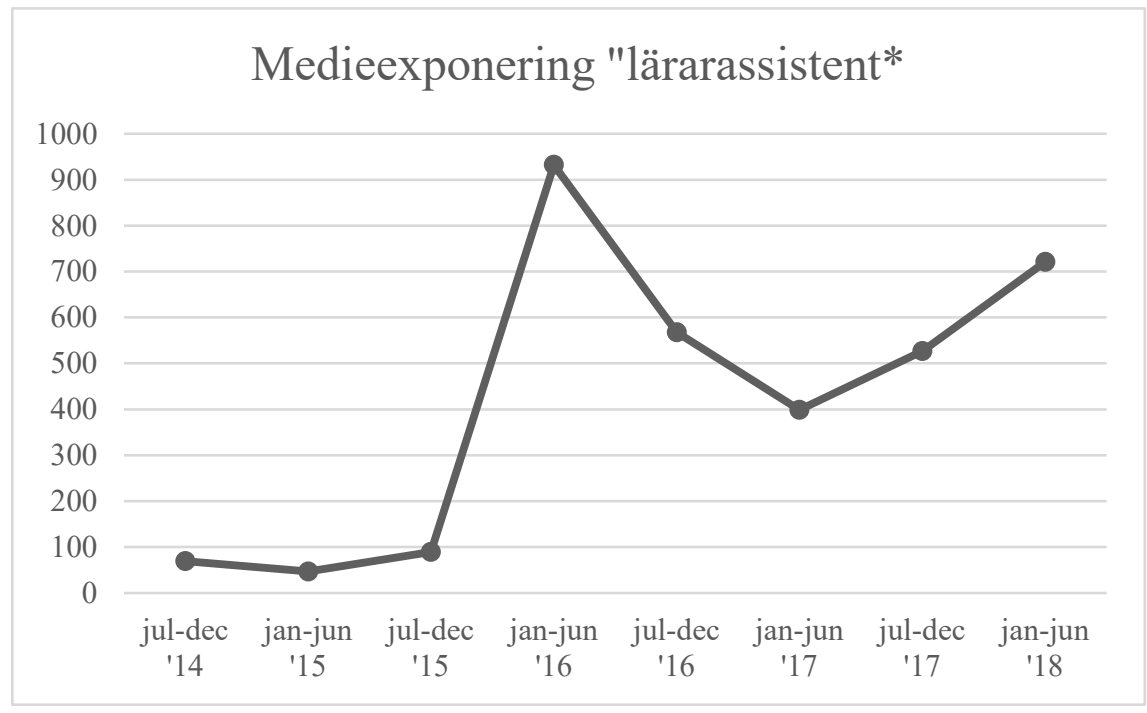

Under den studerade perioden används begreppet 2665 gånger i sammanlagt 351 källor. I ett flertal mediekällor bara vid några enstaka tillfällen. Fördelningen av begreppsanvändningen per källkategori åskådliggörs i figur 2. 
Figur 2. Fördelningen av lärarassistent* per källkategori

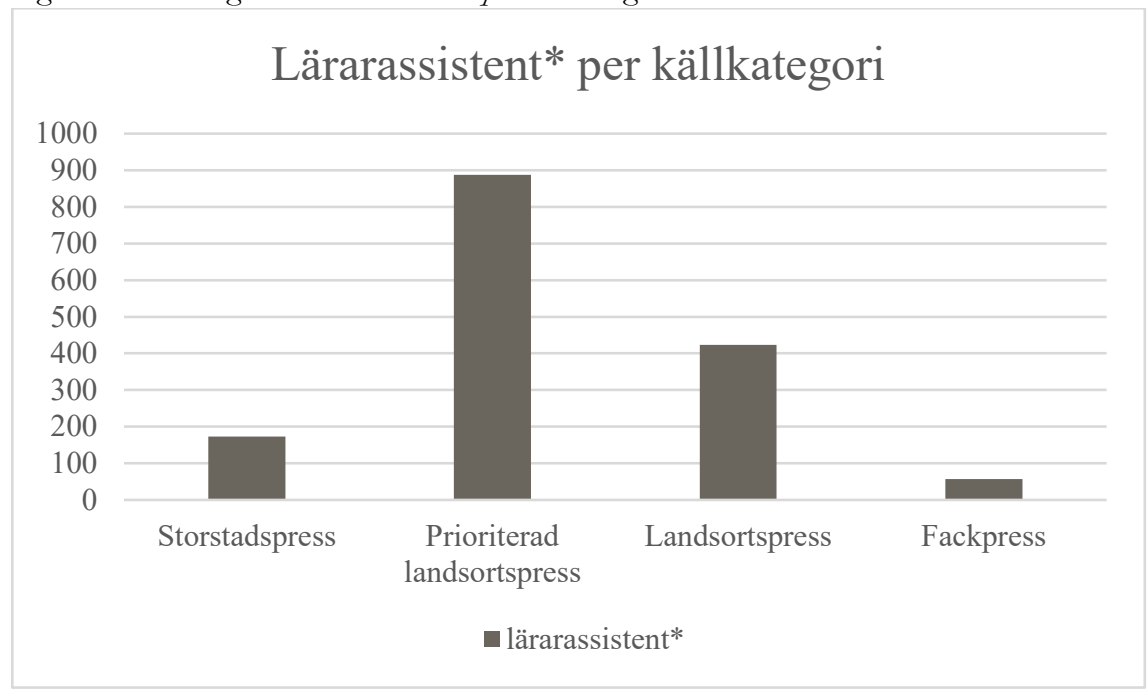

Att begreppet förekommer så frekvent $\mathrm{i}$ landsortspress kan troligen förklaras med dessa källor är betydligt fler än övriga. Här kan dock vissa regionala skillnader konstateras. Bland annat används begreppet mer frekvent i lokala och regionala medier som omfattar Skåne och Västra Götalands län. Att begreppet även rönt stor uppmärksamhet i storstadspress samt i fackpress kan åskådliggöras genom att betrakta de tio mediekällorna som mest frekvent använder begreppet. Av dessa är två fackliga, fem storstadspress och tre landsortspress.

En kategorisering av urval B visar att begreppet lärarassistent framför allt används i reportage eller informationsliknande artiklar om fenomenet (se figur 3). Inte sällan i medias reportage från skolor där lärarassistenter har anställts eller ska anställas samt i reportage som beskriver utbildningar till lärarassistent. Nästan lika många artiklar handlar om att företrädare för politiska partier ges utrymme att föra fram sina argument i frågan. Även de olika fackliga organisationerna ges utrymme. Därutöver skriver tidningarna ledare i frågan och ger visst utrymme för den på debatt- och insändarsidorna. 
Figur 3. Förekomst av lärarassistent* per artikeltyp

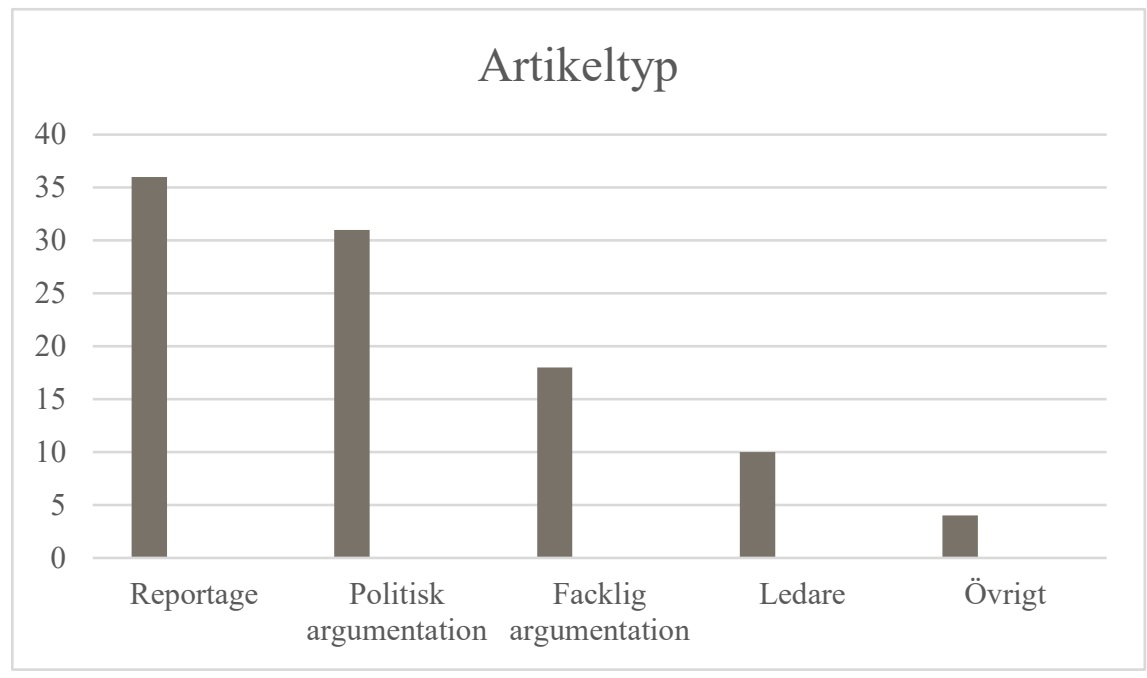

Aktörerna som ges plats i det offentliga samtalet visas i figur 4. Här framgår att den dåvarande regeringen samt oppositionspartierna Moderaterna och Liberalerna ges utrymme. Även fackliga organisationer får plats. Lärarförbundet är det förbund som givits mest utrymme medan Lärarnas riksförbund och SKL inte framträder lika frekvent. Därutöver berörs begreppet lärarassistenter även i ett antal artiklar på tidningarnas ledarsidor. Här kan skönjas ett visst genomslag för liberala och moderata argument eftersom nio av de tio ledartexterna återfinns i obundna liberala eller moderata tidningar.

Figur 4. Aktörer som använder lärarassistent*

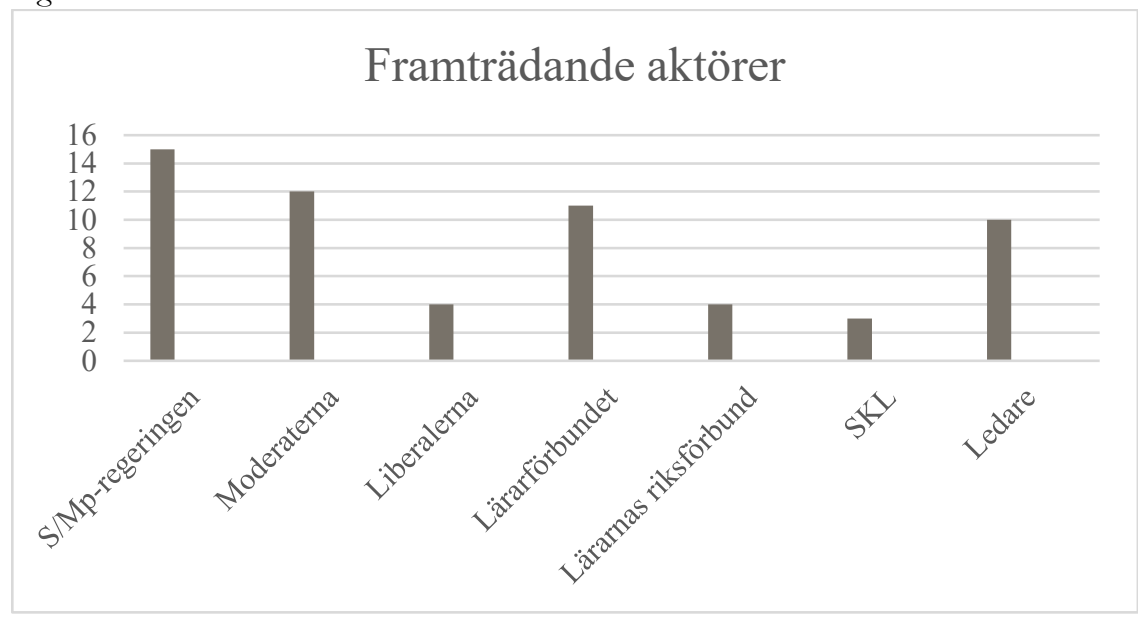


Under slutet av 2014 och hela 2015 förekommer ingen tydlig aktör som tar initiativ $\mathrm{i}$ frågan. Begreppet används till övervägande del i samband med reportage om företeelser eller personer där de senares anställning (som lärarassistent) nämns som en bi-information. På den politiska arenan nämns begreppet för första gången i samband med att en ny regering tillsätts 2014 och den tilltänkte utbildningsministern, $i$ en bisats, föreslår lärarassistenter som avlastning till lärare. Strax efter årsskiftet 2015/2016 börjar begreppet lärarassistenter förekomma mer frekvent. $\mathrm{Nu}$ framträder de aktörer som tar initiativ i frågan. I januari 2016, under loppet av fyra dagar, ges företrädare för de båda lärarfacken samt regeringens minister för högre utbildning utrymme i pressen där de propagerar för införandet av lärarassistenter. I början av mars 2016 kommer Moderaterna med ett utspel om en "storsatsning" på lärarassistenter, vilket följs av ett initiativ från regeringen under slutet av mars samma år att satsa 300 miljoner kronor extra om året på lärarassistenter. Detta följs av ett utspel från Liberalerna, i slutet av april 2016, att satsa 200 miljoner kronor på lärarassistenter. Veckan efter presenterar Moderaterna att även de, i sin vårbudget, satsar 200 miljoner kronor på införandet av lärarassistenter. I maj 2016 gör regeringsföreträdare, tillsammans med företrädare för lärarnas och arbetsgivarnas fackliga organisationer, ett gemensamt utspel om en nationell samling för läraryrket, där de bland annat propagerar för att lärare ska avlastas av andra yrkeskategorier. Under hösten samma år börjar det synas allt fler reportage i pressen om nyanställda lärarassistenter på skolor. Det börjar också dyka upp reportage om de folkhögskolor som startat upp utbildningar till lärarassistenter. Med jämna mellanrum ges även Lärarförbundet tillfälle att argumentera för införandet av lärarassistenter. I april 2017 gör Liberalerna ett utspel om att lärarstudenter kan användas som lärarassistenter. Skolvärlden, Lärarnas riksförbunds fackliga tidskrift, utkommer i augusti 2017 med en undersökning som visar att den kommande lärarbristen kommer att slå olika hårt beroende på var i Sverige skolorna ligger. Detta förmedlas och kommenteras av flera olika tidningar. I kommentarerna anges ofta införandet av lärarassistenter som lösningen på problemet. I januari 2018 ges klartecken för yrkeshögskolan att starta upp utbildningar mot lärarassistent. Även detta beslut förmedlas av flera tidningar. I mars 2018 lanserar socialdemokraterna ett paket för ökad trygghet och studiero i skolorna. Här nämns införandet av lärarassistenter som en sådan åtgärd. I slutet av undersökningsperioden, i juni 2018, gör Alliansen ett utspel där de presenterar ett reformpaket för den svenska skolan, där införandet av lärarassistenter nämns som en del. 


\section{Lärarassistent* - förekomst av argument}

Inför redovisningen av de olika argumenten görs ett nytt urval (urval C) där de reportage- och informationsliknande texterna tas bort. Kvar blir då 85 texter som har en tydlig argumenterande karaktär.

Majoriteten av texterna under våren 2016, då det sker en markant ökning av exponeringen av begreppet lärarassistenter, kopplar ihop behovet av att anställa lärarassistenter med den stora våg av flyktingar som kom till Sverige. Den sägs ge upphov till en volymökning av antal barn och ungdomar i skolan, och därmed spä på de negativa konsekvenserna av den lärarbrist som redan existerar. Införandet av assistenterna föreslås vara lösningen för såväl undervisningen av nyanlända barn som börjar svensk skola som för att nyanlända vuxna ska komma in i arbetslivet. I en ledare i Aftonbladet beskrivs att "Sverige nu växer så det knakar [och att] barnen som kommit hit under hösten kan inte vänta på att deras lärare ska utbildas [det] krävs att någon annan, med annan utbildning, tar över andra delar av jobbet" (Aftonbladet, 2016). Under den resterande perioden av undersökningen kopplas visserligen införandet av lärarassistenter till en kommande lärarbrist men det uttrycks inte längre att flyktingvågen är orsaken. Istället anges till exempel lärares höga arbetsbelastning, elevers fallande kunskapsresultat samt en otrygg arbetsmiljö för såväl lärare som elever som orsaker. Införandet av nya personalkategorier i skolan sägs huvudsakligen kunna avlasta lärarna så att de i första hand ska kunna fokusera på undervisningen och i andra hand få mer tid för eleverna. Man pekar också på att införandet av lärarassistenter kommer att höja läraryrkets attraktivitet så att både rekryteringen och återvändandet till yrket ökar. Dessutom förekommer argument för att nya personalkategorier i skolan kan bidra till en trygg och säker arbetsmiljö på skolor. Lärarförbundet menar också att det skulle kunna leda till att kvaliteten ökar på det arbete som inte hör till undervisningen.

Det förefaller som att det finns en omfattande konsensus i frågan. Endast vid några enstaka tillfällen bemöts argument med kritik. Framför allt moderaternas utspel 2016 kritiseras från fackligt håll. Förslaget tolkas som att lärare måste ta mer undervisningstid om lärarassistenter införs, vilket är något som lärarfacken inte ställer upp på. Även ett lokalt initiativ i Malmö stad om att anställa "grundskolepedagoger [som, under ledning av legitimerade lärare, ska ha ett] undervisande uppdrag" (Sydsvenskan, 2017) bemöts med kritik från lärarfacken. De menar att "grundskolepedagogens arbetsuppgifter är alldeles för likt en lärares arbete" (a.a.) och att det strider mot lagen att tillsvidareanställa icke legitimerade på fasta lärarjobb. Initiativet från Malmö stad lades sedermera ner.

I lärarfackens argumentation kopplas även behovet av assistenter till lärares upplevelser av stress och hög arbetsbelastning. Lärarförbundet anger också som skäl att införandet av nya yrkeskategorier som tar över delar av lärares icke undervisningsrelaterade arbetsuppgifter skulle kunna höja kvaliteten i just 
detta arbete. Moderaterna ser behovet som ett svar på elevernas sjunkande kunskapsresultat. Liberalerna lyfter fram vikten av att komma till rätta med ökad otrygghet och ordningsproblem - "stöket" - i den svenska skolan. Sådana skäl anges också, under den senare delen av undersökningsperioden, av den S/Mp-ledda regeringen vilka också, tillsammans med lärarfacken, anger en höjning av läraryrkets attraktivitet som ett skäl till att införa nya yrkeskategorier i skolan.

De nya yrkeskategorier som beskrivs vara lösningen på ovanstående problem betecknas i de allra flesta texter generellt som "lärarassistenter". Lärarförbundet gör emellertid en uppdelning av avlastande tjänster mellan "administrativa lärarassistenter" och "socialpedagoger" (DN, 2016a). I Sydsvenskan rubriceras avlastningen som "skolvärdsväktare" (Sydsvenskan, 2016a). Andra beteckningar som "elevkoordinator och "grundskolepedagog" används framför allt $i$ texter om Malmö stads initiativ att införa nya typer av tjänster i skolan. I Aftonbladet argumenterar Liberalerna för lärarstudenter i utbildning som en avlastande yrkeskategori. Christer Nylander, gruppledare för Liberalerna beskriver att "...de som går lärarutbildningen ska kunna få jobba mer aktivt i skolan som lärarassistenter" (Aftonbladet, 2017).

Majoriteten texter som argumenterar för lärares avlastning genom införandet av lärarassistenter nämner aldrig att den nya yrkeskategorin ska ha någon formell utbildning och vilken utbildning det $\mathrm{i}$ så fall ska vara. Undantaget är Lärarförbundets argumentation om att införa socialpedagoger som avlastning. Här signalerar beteckningen att kompetensen handlar om att kunna hantera de sociala och elevnära bitarna av lärararbetet. (Socialpedagogutbildning finns som treårig akademisk utbildning på högskolan och som tvåårig utbildning på yrkeshögskola). Även i den text som argumenterar för införandet av skolvärdsväktare förs ett resonemang om vilken kompetens som fordras. Här nämns krav på polisutbildning eller motsvarande.

Om det $\mathrm{i}$ argumentationen saknas uttryck för vilka kompetenser de nya yrkeskategorierna ska ha finns desto fler beskrivningar av vilka arbetsuppgifter de ska utföra. Generellt beskrivs dessa uppgifter som "kringuppgifter". Dessa kan dock vara av lite olika karaktär. För det första handlar det om administrativa uppgifter som till exempel att behandla ledighetsansökningar, hantera frånvaro, schemaläggning och skriva veckobrev till vårdnadshavare. För det andra kopplas uppgifterna till det sociala och elevnära arbetet, som till exempel att agera som stödmentor till elever, vara rastvakt, hantera föräldrakontakter eller ingripa mot stök och oro. För det tredje beskrivs uppgifterna som praktiska. Här anges uppgifter som till exempel kopiering, iordningställande av lokaler och plocka fram och beställa material. För det fjärde och sista handlar det om mer undervisningsnära uppgifter. Dessa anges huvudsakligen i anslutning till 
artiklar om Malmö stads försök att införa grundskolepedagoger samt i förslag om att använda lärarstudenter i skolans verksamhet.

\section{Lärarassistent* - uttryck för differentiering av lärararbetet}

Det offentliga samtalet om lärarassistenter utmärks av en till stora delar oproblematisk och konfliktfri uppdelning av lärararbetet. Friedsons (2001) beskrivning av förhandlingar om verksamhetsdomäner som "an object of struggle among contending groups or classes" (s. 43) verkar inte karaktärisera samtalet. Möjligen kan man se lärarfackens reaktion på Malmö stads försök att ge undervisningsuppdrag till ej lärarutbildade lärarassistenter som en slags gränstvist, där introduktionen av nya yrkesgrupper uppfattas som ett hot mot det professionella projektet och där kärnvärden och gränser för ansvar riskerar att bli ännu mer diffusa samt där lärarfacken använder sig av demarkationsstrategier för att peka ut sitt revir. I en artikel i Sydsvenskan markerar till exempel företrädare för Lärarnas riksförbund gränser genom att argumentera för att "grundskolepedagogens arbete är alldeles för likt en lärares arbete" (Sydsvenskan, 2017).

Även om konsensus till övervägande del präglar samtalet kan argumentationen kring införandet av lärarassistenter ses som en del av lärarkårens professionaliseringsprocess, där yrkesutövarna vill dra sig tillbaka och lämna över delar av arbetet till andra. Viss argumentation indikerar också att dessa delar uppfattas som ovärdiga lärarna och att de kan överlämnas till "para-professionella" yrkesgrupper med lägre status i organisationen (Hasenfeld, 1983). Uttryck av detta återfinns till exempel i Metro-Skåne där man väljer att beskriva överlämnade arbetsuppgifter som "kringsysslor som kan läggas på annan personal, så att legitimerade lärare kan syssla med yrkets kärnuppgifter" (Metro-Skåne, 2016b) eller i Sydsvenskan som beskriver lärarassistenterna som "hjälpreda till lärare på väg in" (Sydsvenskan, 2016b). Många texter ger också uttryck för att en sådan uppdelning av yrket, där läraryrket blir mer "rent" och specialiserat, kommer att ge yrket en högre status och därmed bidra till att göra det mer attraktivt för andra att söka. I Dagens Nyheter hävdar till exempel Lärarförbundet att "Läraryrket måste uppvärderas [...] genom att skolorna anställer administrativa lärarassistenter och socialpedagoger för att avlasta lärarna i deras arbete" (DN, 2016b).

I det offentliga samtalet om införandet av lärarassistenter kan indelningen av yrkets arbetsuppgifter som "smutsiga" och "rena" märkas i hur begrepp används. Bland annat argumenterar Lärarförbundet i Dagens Nyheter för att "Lärarnas uppdrag måste renodlas..." (DN, 2016a). Det "rena" territoriet som kraftigt mutas in är undervisning. Expressens ledarrubrik: "Låt lärarna vara lärare" (Expressen, 2017) är ett återkommande exempel på hur en sådan avgränsning av arbetet markeras. Övriga "smutsiga" arbetsuppgifter, som inte hör till undervisningen beskrivs hamna utanför reviret. Läraryrkets "smutsiga" dimensioner kan förstås på skilda sätt. Antingen som arbets- 
uppgifter ovärdiga läraren, något som till exempel återspeglas i en artikel i Sydsvenskan där en utbildningschef menar att "det är slöseri om en lärare ägnar en stor del av sin tid åt att kopiera eller rastvakta" (Sydsvenskan, 2016b), eller som att läraren är ovärdig uppgiften. Det senare ges uttryck för när Lärarförbundet argumenterar bland annat i Dagens Nyheter för att fler yrkeskategorier - "som kan avlasta lärarna och höja kvaliteten i det arbete som inte direkt hör till undervisningen" (DN, 2016a) - behöver tas in i skolan. I argumentationen för en uppdelning av arbetet ger de alltså utryck för ett tvivel över att den egna kompetensen, vad gäller arbete utanför undervisningsprocessen, är tillräcklig. Ett sådant tvivel rör framför allt de delar av arbetet som tillhör arbetets sociala dimension. Detta arbete inbegriper såväl omsorg om, som fostran av, eleven. Lärarförbundet markerar en avgränsning mot sådant arbete genom att förorda införandet av en ny läraravlastande yrkesgrupp i skolan - socialpedagog - som föreslås arbeta med "elevernas sociala utveckling och spela en viktig roll i samarbetet mellan lärare och elevhälsoteam" [och som ska] "finnas ute bland eleverna under raster och under större delen av skoldagen och förebygga och följa upp situationer och konflikter" [samt] "vara stödmentorer" (DN, 2016a). I media förs flera liknande argument fram som emellertid betonar gränser mot framför allt fostransarbetet. I Sydsvenskan föreslås en ny profession: skolvärdsväktare, vars uppgift ska vara att "skapa lärvänliga, lugna, trygga och säkra miljöer" [samt att] "ta hand om stökiga elever" (Sydsvenskan, 2016a). I samma tidning ges utrymme för socialdemokraterna att argumentera för att introduktionen av lärarassistenter i skolan kan bidra till en "lugn och trygg arbetsmiljö" [samt till] " ökad studiero" (Sydsvenskan, 2018). Man hävdar vidare att lärare ska avlastas genom lärarassistenter "som arbetar trygghetsskapande och har mandat att upprätthålla ordning och studiero" (Metro-Skåne, 2018).

En av utgångspunkterna för studien är att betrakta offentliga samtal i media som en del i skapandet av förutsättningar och villkor för hur lärararbetet tar nya former. För att kunna åstadkomma detta krävs att samtalet påverkar de politiska drivkrafter där beslut fattas som påverkar lagar och regelverk. Det offentliga samtalet i media om införandet av lärarassistenter har till viss del förts av representanter för de politiska partierna. På det sättet har politiska drivkrafter, på ett informellt sätt, såväl påverkat som påverkats av samtalet. Men samtalet återspeglas även på den formella politiska nivån (Urval D). I september 2016 ges ett uppdrag till särskild utredare att bland annat se över lärares administrativa arbetsbörda (Dir 2016:76). Redan i direktivet argumenteras för en uppdelning och renodling av lärararbetet när man skriver att "... det finns behov av att överväga fler åtgärder för att minska lärares administrativa börda för att frigöra tid för undervisning och uppgifter som hör till undervisningen" (s. 24). I början av 2018 kommer utredningens slutbetänkande (SOU 2018:17). Argumentationen från det offentliga samtalet i media känns igen. Utredningen betonar att lärararbetet bör renodlas och att 
lärararbetets kärnuppgift handlar om undervisningsprocessen och att inte bara administration utan även flera av lärares övriga arbetsuppgifter, såsom till exempel det sociala elevnära arbetet, som inte har en direkt koppling till undervisningen, "kan utföras med en högre kvalitet om det utförs av andra professioner eller funktioner med rätt utbildning för uppgiften" (s. 454). Intressant är också att utredningen lyfter fram professionsteoretiska resonemang för att styrka förslaget om en differentiering av lärararbetet. Inspirerade av Aili och Brante (2006) argumenteras för att arbetsuppgifter "ska sättas $\mathrm{i}$ relation till lärare som professionsutövare, och $\mathrm{i}$ vilken utsträckning lärarna utför arbetsuppgifter som legitimerar läraryrket som en autonom profession" (s. 422). Argumentet kopplas till att lärare äger ett formellt kunskapssystem och att uppgifter som "inte kräver tänkande, analys och överväganden utifrån lärarnas formella kunskapssystem" (s. 426) ska göras av andra yrkesgrupper med andra formella kunskapssystem. Utredningen ger exempel på vilka dessa andra yrkesgrupper kan vara och nämner beteendevetare, psykologer, kuratorer och socialpedagoger. Exemplen visar en tydlig markering för att lärararbetets sociala dimension bör begränsas.

Liksom det offentliga samtalet i media hävdas i utredningen att skolan bör utökas med fler personalkategorier för att en specialisering av lärararbetet ska kunna bli möjlig. En sådan specialisering ska, hävdas i utredningen, kunna bidra till att läraryrket framstår som mer attraktivt för såväl de yrkesverksamma som de som ska välja yrke. Utredningen väljer dock att inte föreslå ett nytt specialdestinerat stadsbidrag för personalförstärkningar i skolväsendet utan nöjer sig med att uppmärksamma huvudmän på att använda befintliga stadsbidrag för att kunna ge lärare mer tid för undervisningsprocessen. (Ett specialdestinerat statsbidrag erbjuds emellertid från och med höstterminen 2019.)

\section{DISKUSSION}

I det offentliga samtalet som förts i media om att minska trycket på lärare i Sverige har flera olika förslag förts fram. Under senare år har det emellertid kommit att handla om hur lärare ska kunna avlastas. Argument för en sådan avlastning bygger på idéer om en differentiering av lärararbetet genom införandet av nya yrkeskategorier - lärarassistenter - $\mathrm{i}$ skolorna. Föreliggande studie visar att det offentliga samtalet har präglats av konsensus. Ett sådant resultat visar sig även i andra studier om relationer mellan lärarfacken och utbildningspolicy. Lilja (2014) konstaterar till exempel att det funnits en ömsesidighet mellan den politiska och fackliga agendan som till stor del präglat det offentliga samtalet sedan 2000-talets början och att relationerna mellan de politiska policyaktörerna och lärarfacken under senare tid varit tighta. 
I stort sett samtliga aktörer verkar ha varit överens och fram har tonat ett unisont budskap, en idé om det "rena" lärararbetet där "lärarna ska vara lärare" och ägna sig åt undervisning, åt de rena kärnuppgifterna. Övriga arbetsuppgifter framställs som "smutsiga" på två olika sätt. Å ena sidan bör andra yrkesgrupper utföra dem för att uppgifterna är ovärdiga lärararbetet. Uppgifterna kan därför hellre utföras av assisterande yrkesgrupper med lägre status i organisationen. $\AA$ andra sidan bör andra utföra dem för att lärararbetet är ovärdig uppgifterna. De kan istället utföras - med högre kvalitet - av andra professionella yrkesgrupper med specialistkompetens. I studien visas också hur det offentliga samtalet om lärarassistenter har påverkat de politiska drivkrafter där beslut fattas som påverkar lagar och regelverk. Även i dessa texter argumenteras för en differentiering av lärararbetet, där delar som inte hör till undervisning lika gärna eller ännu hellre kan göras av andra.

Studien visar att exponeringen av begreppet "lärarassistent" i media ökade kraftigt under början av 2016. Anledningar till detta kan bland annat spåras i den eskalerade oro för ökad lärarbrist som flyktingvågen hösten 2015 gav upphov till. Bristen på lärare är redan stor och förväntas bli än större. Enligt Skolverket (2017) är det totala rekryteringsbehovet fram till år 2031, 187000 lärare. Vilket skulle kräva att nästan dubbelt så många skulle behöva påbörja en lärarutbildning varje år. Historiskt sett är förändringar av yrkesdomäner kopplade till stor efterfrågan på arbetskraft (Boyce m.fl., 2011). Att en differentiering av lärararbetet har präglat samtalet om skolan under senare år framstår därför inte som en överraskning. Att en sådan lösning också förespråkas av olika aktörer, med ofta olika intressen, kanske inte heller är förvånande. Här kan möjligen representanter för såväl arbetsgivare och arbetstagare samsas? Det kan finnas anledning för arbetsgivare att hitta ekonomiskt gynnsamma lösningar där billig och flexibel arbetskraft kan överta delar av lärares arbete samtidigt som nuvarande arbetstagare - lärarna - kan utnyttja tillfället för en specialisering och därmed säkra framtida tillgång till privilegier (a.a.). En specialisering genom arbetsdelning kan också fungera som en slags "ångestreducering" (Lipsky, 1980, s. 133) där nya yrkesgrupper gör det möjligt för lärarna att upprätthålla befintliga rutiner. Värdet av en sådan strategi kan emellertid diskuteras. Specialisering har också en baksida. Över tid institutionaliseras de ångestdämpande funktionerna. Det sociala arbetet med elever blir till en institutionaliserad del av lärarassistenternas arbete och i det fall behovet av specialisterna minskar, till exempel när tillgången på lärare blir större än efterfrågan, kan det bli svårt för lärarna att återerövra domänen (Boyce m.fl., 2011, s.195).

I studien har analysen av det offentliga samtalet om lärarassistenter kopplats till lärararbetets verksamhetsdomän. En skola befolkas dock av fler yrkesgrupper med sina respektive domäner. Här finns andra grupper vars verksamhet berör det sociala och elevnära arbetet, som till exempel kuratorer, specialpedagoger och skolsköterskor. Introduktionen av lärarassistenter 
måste kanske också förhålla sig till dessa grupper samt till de omförhandlingar om domäner, såväl mellan yrkesgrupperna som mellan dessa och lärarkåren, som ständigt återkommer. Möjligen kan man i sammanhanget likna införandet av lärarassistenter i svenska skolor vid att en ny (yrkes)art etableras i ett ekosystem där den nya arten konkurrerar med ursprungsarterna om samma revir, resurser och byten. Utbredningen av lärarassistenter kan alltså få effekter för övriga gruppers utbredning. Finns det till exempel risk för att antalet skolkuratorer kommer att minska när lärarassistenter introduceras $i$ svenska skolor?

Olika studier (exempelvis Landahl, 2006; Backlund, 2007) har visat hur lärararbetets sociala dimension, där arbetsuppgifter som rör fostran av och omsorg om barn/elever ingår, har expanderat under slutet av 1900-talet och början av 2000-talet. Föreliggande studie visar emellertid att samtalet om införande av lärarassistenter i de svenska skolorna kan ses som ett steg på väg tillbaka mot en reduktion av lärararbetets sociala dimension, där lärarassistenter tar hand om det elevnära arbetet och där lärarens utsträckning från klassrummet begränsas. Troligen får detta konsekvenser för lärarnas elever. Förändringar i läraryrkets verksamhetsdomän kan också innebära förskjutningar i synen på vilka skolbarn som ska bemötas av lärare och hur ett skolbarn ska bemötas av lärare (Landahl, 2006). Förhandlingen om en differentiering av läraryrket, där nya yrkeskategorier övertar delar av lärares arbete, kan ses som en professionaliseringsprocess där en uppdelning sker av vad som är problem och vem som ska lösa dem. Hasenfeld (1983) beskriver i sin analys av professionaliseringsprocesser inom välfärdstiänster (Human service organizations) hur professioner avgränsar sina domäner genom att delegera "smutsigt" arbete samt öka den sociala distansen till "less-desirable clients" (a.a., s. 165). Studier av lärarassistenters (teaching assistants) arbete $i$ England bekräftar sådana processer. Bland annat visar Giangreco, Edelman och Broer (2001) att arbetsuppgifterna för lärarassistenterna visserligen tenderar att bli mer avancerade och lärarliknande över tid och att assistenterna efter hand framstår som "quasi-teachers" (s. 490) men att de oftast ges ansvar för undervisning av elever $\mathrm{i}$ behov av särskilt stöd (a.a.), elever som troligen är i störst behov av undervisning av utbildade pedagoger.

Föreliggande artikel har uppmärksammat vilka olika idéer om lärararbetet som trätt fram och som givits dominans $i$ det offentliga samtalet om lärarassistenter. Ledtrådar har också givits till hur det offentliga samtalet kan vara en del i skapandet av förutsättningar och villkor för hur lärararbetet tar nya former. Dessutom har diskuterats hur introduktionen av en avlastande yrkesgrupp kan komma att påverka existerande yrkesgrupper i skolan och dess elever. Diskussionen skrapar emellertid bara på ytan. Behovet är stort av forskning om vad som händer när idéerna färdas vidare till, och får fäste i, skolans kontext; om de effekter som uppstår när fenomenet "lärarassistenter" institutionaliseras. För närvarande är området tämligen outforskat. Före- 
liggande studie ingår $\mathrm{i}$ ett forskningsprojekt som tillhör undantagen. I projektet $A v$-eller belastning? Ett projelet om lärare, lärarassistenter och förhandlingar om professionella gränser, finansierat av Forte, studeras inte bara de idéer om avlastning som speglas i policy och praktik. Här undersöks även föreställningar av önskvärda avgränsningar mellan professionella domäner som beskrivs av de yrkesverksamma själva samt hur faktiska processer ser ut där nya sätt att dela upp arbetet introduceras i skolan. Förhoppningsvis kan kommande resultat från projektet generera en introducerande kunskapsbas som dels ger ledtrådar till vidare forskning inom området, dels bidrar med underlag för diskussioner kring utformning av och innehåll i nya avlastande tjänster inom den svenska skolan.

\section{KÄLLMATERIAL}

Aftonbladet, 2016. Polis och lärare måste få jobba. Publicerat 2016-01-27.

Aftonbladet, 2017. Så vill Björklund rädda skolan. Liberalerna föreslår satsning på 'skolmiljard': Mer ordning och reda. Publicerad 2017-04-23.

Dir 2016:76. Bättre skola genom mer attraktiva professioner. Kommittédirektiv Utbildningsdepartementet.

DN, 2016a. Anställ fler yrkeskategorier för att klara lärarbristen. Publicerad 2016-01-25.

DN, 2016b. Gymnasieexamen vägen till arbete för nyanlända. Publicerad 2016-07-06.

Expressen, 2017. Làt lärarna vara lärare. Publicerad 2017-01-25.

Metro-Skåne, 2016. Lärare föreslår assistenter för att minska arbetsbördan. Publicerad 2016-01-22.

Metro-Skåne, 2018, Mobifförbud i klassrum ska vara normalläget. Publicerad 2018-06-04.

SOU 2018:17. Med undervisningsskicklighet $i$ centrum - ett ramverk. för lärares och rektorers professionella utveckling. Stockholm: Utbildningsdepartementet.

Stark, E. (2019). Den goda skolan - i lagens namn eller en trygghetens famn? Diskurser om skolproblem i lokal media och bland skolverksamma. Umeå universitet: Statsvetenskapliga institutionen.

Sydsvenskan, 2016a. Inför skolvärdsväktare för att skapa en lärvänlig och säker miljö $i$ skolan. Publicerad 2016-10-06.

Sydsvenskan, 2016b. Hjälpreda till lärare på väg in. Publicerad 2016-03-14.

Sydsvenskan, 2017. Obehöriga kan få fast jobb. Publicerad 2017-09-18.

Sydsvenskan, 2018. S: Ska vara enklare att flytta elever som bråkar. Ministern: Ingen tvekan om vem som bestämmer. Publicerad 2018-03-28. 


\section{REFERENSER}

Abbott, Andrew (1988). The system of professions. An essay on the division of expert labor. Chicago: University of Chicago Press.

Aili, Carola, \& Brante, Göran (2006). Kvalificerande arbete - lärares vardagliga arbete som bas för lärarprofessionens autonomi. Stockholm: Lärarförbundet.

Alhamdan, Bandar, Al-Saadi, Khalid, Baroutsis, Aspa, Du Plessis, Anna, Hamid, Obaidul M.,\& Honan, Eileen (2014). Media representation of teachers across five countries. Comparative Education, 50(4), 490-505.

Alvesson, Mats, \& Sköldberg, Kaj (1994). Tolkning och reflektion. Vetenskapsfilosofi och kvalitativ metod. Lund: Studentlitteratur.

Anderson, Gary (2007). Media's impact on educational policies and practices: Political spectacle and social control. The Peabody Journal of Education, 82(1), 103120.

Backlund, Åsa (2007). Elevvård i grundskolan - resurser, organisering och praktik. Rapport i socialt arbeten nr. 121, Stockholms universitet, Institutionen för socialt arbete.

Bejerot, Eva, Forsberg Kankkunen, Tina, \& Hasselbladh, Hans (2015). Två decennier av new public management: arbetsmiljön i skola och sjukvård. Arbetsmarknad och arbetsliv, 21(3), 23-41.

Bergström, Göran \& Beréus, Kristina (2000). Textens mening och makt. Metodbok i sambällsvetenskeaplig textanalys. Lund: Studentlitteratur.

Boyce, Rosalie, A., Borthwick, Alan, Moran, Monica, \& Nancarrow, Susan (2011). Health Workforce Reform: Dynamic Shifts in the Division of Labour and the Implications for Intrapersonal Education and Practice. I S. Kitto, \& J. Chesters (Red.) Sociology of Interprofessional Health (s. 186-205). Nova Science Publishers.

Bryman, Alan (2008). Sambällsvetenskapliga metoder (uppl. 2). Malmö: Liber.

Cohen, Jennifer L. (2010). Teachers in the news: a critical analysis of one US newspaper's discourse on education, 2006-2007. Discourse: Studies in the Cultural Politics of Education, 31(1), 105-119. https://doi.org/10.1080/01596300903465450

Dir 2016:76. Bättre skola genom mer attraktiva skolprofessioner. Kommittédirektiv, Utbildningsdepartementet.

DN (2016a). "Anställ fler yrkeskategorier för att klara lärarbristen". Dagens Nyheter. Tillgänglig: https://www.dn.se/debatt/anstall-fler-yrkeskategorier-for-att-klaralararbristen/

Douglas, Mary (1966/1992). Purity and danger. An analysis of the concepts of pollution and taboo. London: Routledge. 
Edling, Silvia, \& Liljestrand, Johan (2019). Let's talk about teacher education!

Analysing the media debates in 2016-2017 on teacher education using Sweden as a case. Asia-Pacific Journal of Teacher Education, 1-16. https://doi.org/10.1080/1359866X.2019.1631255

Elstad, Eyvind (2009). Schools which are named, shamed and blamed by the media: school accountability in Norway. Educational Assessment, Evaluation and Accountability, 21(2), 173-189. https://doi.org/10.1007/s11092-009-9076-0

Englund, Tomas (1999): Talet om likvärdighet i svensk utbildningspolitik. I C. A. Säfström \& L. Östman (red). Textanalys (s. 325-346). Lund: Studentlitteratur.

Folke-Fichtelius, Maria (2003). Utbildningspolitik och medielogik: En fallstudie om mediernas funktion $i$ debatten om skolan. Rapporter om utbildning. Uppsala: Uppsala universitet.

Friedson, Eliot (2001). Professionalism. The third logic. Cambridge: Polity Press.

Giangreco, Michael, Edelman, Susan, \& Broer, Stephen (2001). Respect appreciation and acknowledgment of paraprofessionals who support students with disabilities. Exceptional children, 67(4), 485-498. https://doi.org/10.1177/001440290106700404

Grape, Ove, Blom, Björn, \& Johansson, Roine (red.) (2010). Organisation och omvärld: nyinstitutionell analys av människobehandlande organisationer. Lund: Studentlitteratur.

Hansen, Anders (2009). Researching teachers in the news: The portrayal of teachers in the British national and regional press. Education 3-13, 37(4), 335-347.

Hasenfeld, Yeheskel (1983). Human service organizations. Englewood Cliffs, NJ: Prentice Hall.

Hsieh, Hsiu-Fang, \& Shannon, Sarah E. (2005). Three approaches to qualitative content analysis. Qualitative Health Research, 15(9), 1277-1288. https://doi.org/10.1177/1049732305276687

Hattam, Robert, Prosser, Brenton, \& Brady, Kathy (2009). Revolution or backlash? The mediatisation of educational policy in Australia. Critical Studies in Education, 50(2), 159-172).

Isaksson, Christine \& Larsson, Anna (2012). Skolkuratorsyrkets framväxt och utveckling i Sverige. Socionomens forskningssupplement, 32(6), 24-33.

Landahl, Joakim (2006). Auktoritet och ansvar. Lärares fostrans- och omsorgsarbete $i$ bistorisk belysning. Arbetsliv i omvandling 2006:2. Stockholm: Arbetslivsinstitutet.

Lilja, Peter (2014). Negotiating teacher professionalism. On the symbolic politics of Swedish teacher unions. Malmö: Malmö university, faculty of education and society.

Lindensjö, Bo, \& Lundgren, Ulf P. (2000). Utbildningsreformer och politisk styrning. Stockholm: HLS Förlag. 
Lipsky, Michael (1980). Street-level bureaucracy. Dilemmas of the individual in public services. New York: Russell Sage Foundation.

Melander, Fredrik (2004). Kris i skolan? En analys av den aktuella svenska skoldiskursen. I Nära gränsen? Perspektiv på skolans arbetsliv (s. 287-317). Stockholm: Arbetslivsinstitutet.

Myndigheten för press, radio och TV (2019). Medieutveckling 20019 - Mediemångfald. Rapport från myndigheten för press, radio och TV. https://www.mprt.se/Documents/Publikationer/Medieutveckling

Persson, Sofia (2008). Läraryrkets uppkomst och förändring. En sociologisk studie av lärares villker, organisering och yrkesprojekt inom den grundläggande utbildningen i Sverige ca. 18002000. Göteborg: Göteborgs universitet.

Piazza, Peter (2014). The media got it wrong! A critical discourse analysis of changes to the educational policy making arena. Education Policy Analysis Archives, 22(36), 1-27.

Reimers, Eva (2014). Discourses of education and constitutions of class: Public discourses on education in Swedish PBS Television. Discourse: Studies in the Cultural Politics of Education, 35(4), 540-553.

Ringarp, Johanna (2011). Professionens problematik. Lärarkårens kommunalisering och välfärdsstatens förvandling. Diss. Stockholm: Makadam.

Sjöberg, Lena (2010). Lärarprofessionalism på glid. Performativ förskjutning av statlig och lärarfacklig utbildningspolicy. Pedagogisk forskning i Sverige, 15(1), 18-32.

Skolverket (2017). Redovisning av regeringsuppdrag. Dnr 2016: 906.

Skolvärlden (2017). Så ska skolans tidstjuvar soppas. Hämtad 2018-10-11 från http://skolvarlden.se/artiklar/stoppa-tidstjuven

SOU 2016:35. Vägen in i det svenska skolväsendet. Stockholm:

Utbildningsdepartementet.

SOU 2018:17. Med undervisningsskicklighet $i$ centrum - ett ramverk för lärares och rektorers professionella utveckling. Stockholm: Utbildningsdepartementet.

Strömbäck, Jesper (2009). Makt, medier och sambälle: en introduktion till politisk kommunikation. Stockholm: SNS förlag.

Strömbäck, Jesper, \& Esser, Frank (2014). Mediatization of Politics: Towards a Theoretical Framework. I F. Esser \& J. Strömbäck (red), Mediatization of politics. Understanding the transformation of Western democracies (s. 3-28). Basingstoke: Palgrave Macmillan.

SvD (2016). "Assistenter behörs för att avlasta lärarna". Svenska Dagbladet. Tillgänglig: https://www.svd.se/assistenter-behovs-for-att-avlasta-lararna 
Thomas, Sue (2011). Teachers and public engagement: an argument for rethinking teacher professionalism to challenge deficit discourses in the public sphere. Discourse: Studies in The Cultural Politics of Education, 32(3), 371-382.

UKÄ (2016). Fortsatt fler söker sig till lärarutbildningen - men längt ifrän det prognostiserade behovet. Statistisk analys 2016-09-19 / 2

Wiklund, Matilda (2006). Kunskapens fanbärare. Den goda läraren som diskursiv konstruktion på en mediearena. Avhandling. Örebro: Örebro universitet.

Wiklund, Matilda (2018). The media end the making of educational policy - An analysis of media discourse on education in two Swedish election periods. Journal for Critical Education Policy Studies, 16(2), 99-134. 